\title{
CARCASS VALUE AND THE COMPOSITION OF MEAT FROM STEERS FED A DIET CONTAINING PROCESSED SWINE WASTE
}

\author{
J. GILKA, Z. MATYÁŠ, I. INGR, O. ZATOČIL
}

Veterinary Research Institute, 62132 Brno

Department of Food Hygiene and Technology, University of Veterinary Science, 61242 Brno

Received fuly 12, 1978

\begin{abstract}
Gilka, J., Z. Matyáš, I. Ingr, O. Zatočil: Carcass Value and the Composition of Meat from Steers Fed a Diet Containing Processed Swine Waste. Acta vet. Brno, 47, 1978: $103-112$.

A study was made on carcass value and some characteristics of the meat and fat from 6 experimental steers fed a diet containing processed swine waste for four weeks. The nutritional status of the animals and their carcasses was classified as very good. No changes suggestive of a nutritional disorder were revealed at premortem and postmortem veterinary examination. Sensory properties of the meat were typical and specific. Dressing percentage, the proportions of the individual parts of the carcasses and the proportions of the tissues in the individual cut parts corresponded to the values for Bohemian Red Spotted steers. The composition of the meat was within limits corresponding to beef. The fatty acid composition of intramuscular and depot fats and the fat-producing capacity of adipose tissues corresponded to the values reported for cattle. None of the characteristics under study appeared to be affected by the diet.
\end{abstract}

Swine waste, feeding, steer, meat and fat characteristics.

Waste produced by pigs in large production units amounts to considerable quantities (daily excreta production of the pig varies between 0.3 and $3 \mathrm{~kg}-$ Holub et al. 1969). The disposal of swine waste onto the land which was the usual practice in the past, is considered uneconomic in view of the cost of handling (Wadleigh 1968). Since swine waste has a certain nutritional value, the possibility of its recycling by feeding has been considered (Fontenot and Webb 1975). Dried swine waste was reported to contain 21.6 per cent crude protein (Orr et al. 1971).

The utilization of animal waste as feed is stimulated by three main interests: (1) disposing of animal waste by beneficial and economical means, (2) reducing environmental pollution and (3) sparing the land used in the production of feeds for crops that can be used directly for human consumption (E1 Sabban et al. 1970).

Many compounds present in food can be regarded as nutritional stress factors (Lepkovsky 1953). Metabolic reactions to stress may change the composition of muscle and thus affect the characteristics of meat (Lawrie 1966). Considering its origin and composition, animal waste in the ration might cause animal health hazard and affect the production and quality of foodstuffs from such animals. With this in view, a preliminary study was made on the quality of meat and fat from animals fed swine waste as part of the ration to find whether this unorthodox feed constituent can be used in animals at all and whether it would affect the outcome of meat inspection as to fitness for human consumption.

\section{Materials and Methods}

Six feedlot steers of the Bohemian Red Spotted breed averaging $454 \mathrm{~kg}$ at the beginning of the study were employed. The first object was to find whether the steers would consume concentrated swine waste. The swine waste contained cir. 25 per cent dry matter consisting of 40.3 per cent 
total nitrogenous substances, 3.22 per cent crude fat and 22 per cent ash (of this $2.71 \% \mathrm{Ca}, 8.97 \%$ $\mathrm{K}, 2.03 \% \mathrm{Na}$ and $1.75 \% \mathrm{P}$ ) (Švanda et al. 1976). The product of paste-like consistency was mixed with maize silage. The waste-silage mixture had an unpleasant odour and was refused by the animals at first and consumed with reluctance later on; no digestive disorders during the experimental period of feeding were observed (Síč, Dedek 1975). The steers were fed a concentrate mixture consisting of barley meal supplemented with either cotton cattle-cake or concentrated swine waste ( $1.5 \mathrm{~kg}$ dry matter per animal per day). In the first phase of the feeding experiment 3 steers were fed cattle cake (Group II) and 3 steers swine waste for a 28-day period (Group I). In the second phase of the experiment 3 steers (Group I) were fed a ration in which swine waste was replaced with cattle cake and the other 3 steers (Group II) received swine waste for 31 days up to slaughter. The animals in Group I were slaughtered after swine waste had been withdrawn from their diet for 25 days. All steers were transported for slaughter to a distance of $35 \mathrm{~km}$ in a lorry and slaughtered afier a rest of 18 hours during which time water, but no food was available.

Blood was collected at exsanguination and whole blood extracts were prepared with trichloroacetic acid and alkaline solution of zinc sulphate in the same way as used in preparing muscle extracts (see below). Meat and fat production was evaluated by weighing the quarters while warm, expressing their proportions as percentages of the live body mass and calculating the dressing percentage. After beeing cooled for $\mathbf{4 8}$ hours, the quarters were cut and the main parts (rump + + round, shoulder and strip loin) were separated and their proportions were expressed as percentages of the cooled quarters. The proportions of meat, bone, fat and tendon were calculated as percentages of each separated cooled part. Sensory examination was carried out at the processing of the carcasses by visual inspection to detect possible colour divergencies and particularly by smell to perceive possible divergencies from the normal odour at the opening of the body cavities and in the folds of the carcasses. The main sensory testing for flavour was made on boiled and roasted samples of $\mathrm{m}$. longissimus dorsi, diaphragm and liver (Sborník veterinárních předpisů, 1962) after 9 days of ageing in a cold room.

Chemical examination was carried out on $\mathrm{m}$. longissimus dorsi above the 9th to 11 th ribs, and on the diaphragm. The muscles were removed immediately after dressing (about $11 / 2$ hours after exsanguination) and dissected free from surface connective and adipose tissue without delay, and adequate amounts of the muscles were ground in a meat cutter. The ground meat was throughly mixed and samples were taken for the determination of water, fat, total nitrogen and ash (Prozatimní zkušební metody pro maso, 1958), glycogen (anthron method, Keil and Šormová 1959), hydroxyproline (Ârneth and Hamm 1971) total muscle pigment (Hornsey 1956), and "free water" content (Grau and Hamm 1957; a $2 \mathrm{~kg}$ weight was employed for compression). From the ground muscles the following extracts were prepared: aqueous extract $(1: 3)$ for $\mathrm{pH}$ measurement and ammonia determination (by diffusion in Conway's dishes - Dvo řák 1958), extract with chilled $5 \%$ trichloracetic acid (1:9) in a homogenizing apparatus, and, similarly, extract with chilled alkaline solution of zinc sulphate (Henry 1964). The acid extract was used for the determination of lactic acid (according to Barker and Summerson - Henry 1964), inorganic phosphate as phosphorus (Hořejší 1964), nonprotein nitrogen (by nesslerization Henry 1964) and ninhydrin-positive substances (i. e. mainly free amino acids and low-molecular weight peptides) (Homolka 1971). The alkaline extract was used for the determination of glucose (according to Folin-Wu - Henry 1964).

Fatty acid composition was analysed in intramuscular fat of the collected muscle samples (from $\mathrm{m}$. longissimus dorsi from one animal only because of the difficulty in separating the scarce fat), and in perinephric, intestinal, pericardial and subcutaneous tail fat. Fat was separated from adipose and muscle tissues by homogenizing the samples with chloroform-methanol $(10: 1$ and 2:1 respectively). The fats thus obtained were saponified. Methyl esters were prepared from the liberated fatty acids and analysed by gas-chromatography (Czechoslovak CHROM 2 chromatograph with a flame ionization detector) (Ingr 1971). To follow the influence of the diet on fat metabolism, catalase activity was determined (Zatočil, Śtíchová, and Stícha 1974) in a prototype semi-automatic apparatus developed in the Dept. of Food Hygiene and Technology of the University of Veterinary Science, Brno. The catalase activity (Ca) was related to the fat-producing capacity (FPC) of each adipose tissue using the formula FCP $=\frac{F}{\text { FFT }}$ where $F$ is fat and FFT is fat-free tissue. The fat was extracted with petroleum ether and $\mathrm{Ca}$ was determined according to a single interval with maximum oxygen production resulting from hydrogen peroxide decomposition of FFT by catalase.

Since swine waste was fed for 28 days and withdrawn from the diet 25 days before slaughter in Group I, but was fed till slaughter in Group II, the significance of the differences between the two groups was assessed by Student's $t$-test. 
Table 1

Carcass value of 6 experimental steers fed a ration containing processed swine waste (Means \pm S. D),

\begin{tabular}{|c|c|c|c|}
\hline & $\bar{x}$ & S. D. & $\boldsymbol{V} \%$ \\
\hline 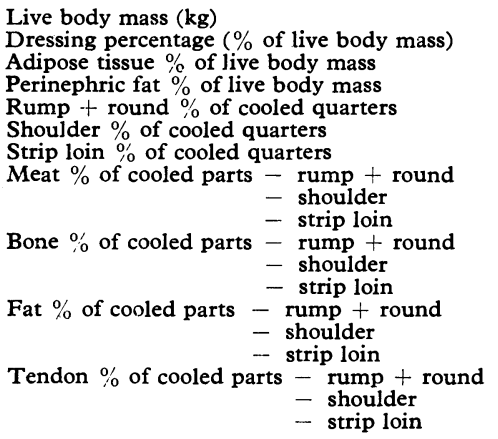 & $\begin{array}{r}490.33 \\
58.77 \\
3.23 \\
1.60 \\
32.77 \\
16.69 \\
8.10 \\
79.99 \\
77.26 \\
74.56 \\
16.88 \\
18.51 \\
18.44 \\
2.01 \\
3.16 \\
5.75 \\
0.93 \\
1.30 \\
1.17\end{array}$ & $\begin{array}{r}16.94 \\
1.89 \\
0.87 \\
0.51 \\
3.00 \\
1.06 \\
0.82 \\
0.84 \\
1.87 \\
3.48 \\
0.70 \\
1.39 \\
3.04 \\
0.46 \\
1.13 \\
2.58 \\
0.17 \\
0.22 \\
0.25\end{array}$ & $\begin{array}{c}9.94 \\
3.21 \\
26.93 \downarrow \downarrow \\
31.68 \downarrow \\
9.18 \\
6.34 \\
10.17 \\
1.04 \\
2.43 \uparrow \uparrow \\
4.67 \uparrow \uparrow \\
4.12 \\
7.54 \\
16.47 \\
22.74 \\
35.87 \downarrow \downarrow \\
44.94 \\
18.77 \\
16.86 \\
21.08\end{array}$ \\
\hline
\end{tabular}

Table 2

Some characteristics of the blood collected at slaughter from 6 experimental steers fed a diet containing processed swine waste (Means \pm S. D.)

\begin{tabular}{|c|c|c|c|}
\hline Characteristic & $\tilde{x}$ & S. D. & V \\
\hline $\begin{array}{l}\left.\text { Glucose (mmol } .1-^{1}\right) \\
\left.\text { Lactic acid (mmol } .1-^{-1}\right) \\
\text { Inorganic phosphorus }\left(\mathrm{mmol} .1-^{-1}\right) \\
\left.\text { Nonprotein nitrogen (mmol } 1-^{-1}\right) \\
\text { Ninhydrin-positive substances }\left(\mathrm{g} \cdot 1-^{-1}\right) \\
\left.\text { Urea (mmol } .1-^{1}\right)\end{array}$ & $\begin{array}{r}2.64 \\
3.47 \\
16.76 \\
60.62 \\
0.07 \\
4.84\end{array}$ & $\begin{array}{l}0.57 \\
1.49 \\
7.49 \\
5.00 \\
0.03 \\
0.43\end{array}$ & $\begin{array}{l}21.66 \\
44.05 \downarrow \downarrow \\
44.63 \\
8.31 \\
40.33 \\
9.15 \downarrow\end{array}$ \\
\hline
\end{tabular}

Table 3

Basic percentage composition of the meat from 6 experimental steers fed a diet containing processed swine waste (Means \pm S. D.)

\begin{tabular}{|c|c|c|c|c|c|c|}
\hline \multirow{2}{*}{ Characteristic } & \multicolumn{3}{|c|}{ M. longissimus dorsi } & \multicolumn{3}{|c|}{ Diaphragm } \\
\hline & $\bar{x}$ & S. D. & $\mathbf{V}$ & $\bar{x}$ & S. D. & V \\
\hline $\begin{array}{l}\text { Water } \\
\text { Intramuscular fat } \\
\text { (ether extract) }\end{array}$ & $\begin{array}{r}75.26 \\
0.79\end{array}$ & $\begin{array}{l}0.88 \\
0.23\end{array}$ & $\begin{array}{r}1.17 \\
29.23\end{array}$ & $\begin{array}{r}74.10 \\
2.99\end{array}$ & $\begin{array}{l}1.30 \\
0.28\end{array}$ & $\begin{array}{l}1.75 \\
9.28 \uparrow\end{array}$ \\
\hline $\begin{array}{l}\text { Protein }(\mathrm{N} \times 6.25) \\
\text { Ash } \\
\text { Carbohydrates (glycogen) }\end{array}$ & $\begin{array}{r}20.86 \\
1.05 \\
0.80\end{array}$ & $\begin{array}{l}1.13 \\
0.04 \\
0.12\end{array}$ & $\begin{array}{r}5.44 \\
3.61 \\
15.53\end{array}$ & $\begin{array}{r}20.30 \\
1.13 \\
0.82\end{array}$ & $\begin{array}{l}1.16 \\
0.02 \\
0.24\end{array}$ & $\begin{array}{r}5.73 \\
1.65 \\
29.29\end{array}$ \\
\hline
\end{tabular}

\section{Results}

The experimental steers were in a very good nutritional condition (Grade A-B) and showed no signs of disease or disorder when examined before slaughter. At post-slaughter inspection the carcasses were well muscled as evidenced by dressing percentage (Table 1 ) and showed no pathoanatomical changes suggestive of a nutritional disorder.

By sensory examination at the processing of the carcasses no colour or odour 
Table 4

Some characteristics of the meat from 6 experimental steers fed a diet containing processed swine waste (Means \pm S. D.)

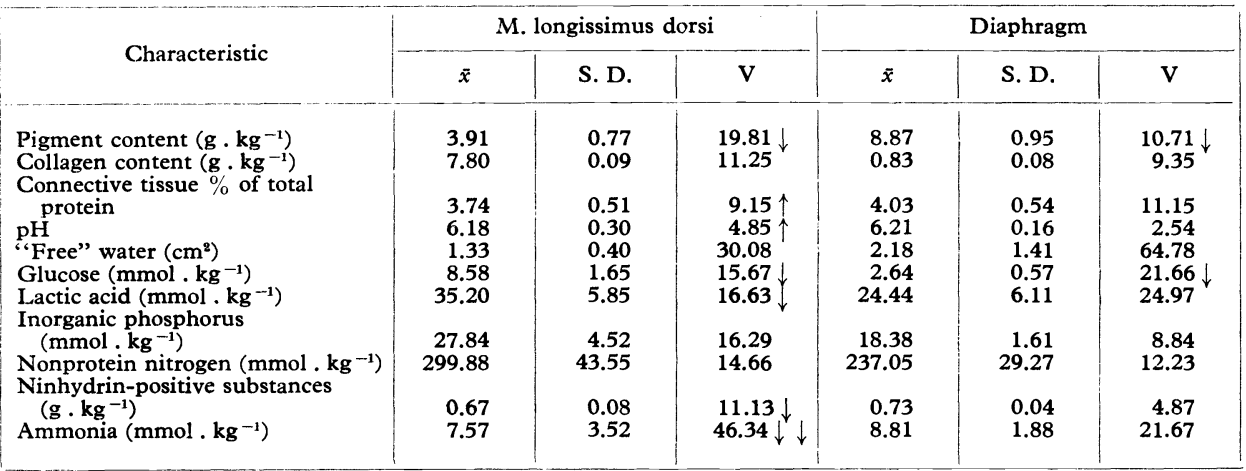

Table 5

Fatty acis composition (as mass $\%$ of total fatty acids) of adipose tissues from experimental steers fed a ration containing processed swine waste (averages from 6 steers, except for $\mathrm{m}$. longissimus dorsi where only one animal was evaluated

\begin{tabular}{|c|c|c|c|c|c|c|c|c|c|}
\hline & $14: 0$ & $14: 1$ & $16: 0$ & $16: 1$ & $17: 0$ & $17: 1$ & $18: 0$ & $18: 1$ & $18: 2$ \\
\hline $\begin{array}{l}\text { Subcutaneous tail fat } \\
\text { Pericardial fat } \\
\text { Intestinal fat } \\
\text { Perinephric fat } \\
\text { Diaphragmatic fat } \\
\text { M. longissimus dorsi fat }\end{array}$ & $\begin{array}{l}6.2 \\
6.3 \\
5.5 \downarrow \\
5.5 \\
4.4 \\
4.1\end{array}$ & $\begin{array}{l}2.4 \\
0.7 \\
0.8 \\
0.7 \\
0.5 \downarrow \\
0.9\end{array}$ & $\begin{array}{l}19.6 \\
18.8 \\
19.5 \\
20.0 \\
19.4 \\
21.2\end{array}$ & $\begin{array}{l}3.9 \downarrow \\
0.4 \\
0.4 \\
0.5 \\
1.3 \\
3.1\end{array}$ & $\begin{array}{l}1.9 \\
0.9 \uparrow \\
0.8 \\
0.6 \\
2.0 \\
1.1\end{array}$ & $\begin{array}{l}1.2 \\
3.8 \\
3.8 \\
3.0 \\
0.6 \\
0.9\end{array}$ & $\begin{array}{l}25.6 \\
31.9 \\
32.6 \\
33.7 \\
30.4 \\
24.0\end{array}$ & $\begin{array}{l}35.7 \\
31.7 \\
31.3 \\
31.9 \\
34.9 \\
40.4\end{array}$ & $\begin{array}{l}1.4 \\
2.7 \\
1.9 \downarrow \downarrow \\
1.4 \\
4.9 \\
3.1\end{array}$ \\
\hline & & \multicolumn{4}{|c|}{ Total saturated fatty acids } & \multicolumn{4}{|c|}{ Total unsaturated fatty acids } \\
\hline $\begin{array}{l}\text { Subcutaneous tail fat } \\
\text { Pericardial fat } \\
\text { Intestinal fat } \\
\text { Perinephric fat } \\
\text { Diaphragmatic fat } \\
\text { M. longissimus dorsi fat }\end{array}$ & & & \multicolumn{3}{|c|}{$\begin{array}{l}55.3 \uparrow \\
60.5 \\
61.7 \\
62.3 \\
57.8 \\
51.6\end{array}$} & \multicolumn{4}{|c|}{$\begin{array}{l}44.7 \\
39.5 \\
38.3 \\
37.7 \\
42.2 \\
48.4\end{array}$} \\
\hline
\end{tabular}

Table 6

Relation between catalase activity (CA) and fat-producing capacity (FPC) of adipose tissues from experimental steers fed a ration containing processed swine waste till slaughter. Catalase activity is expressed as mean maximum gas volume $\left(V_{\max }\right)$ per second $(s)$ and $\mathrm{g}$ of fat-free tissue (FFT)

\begin{tabular}{|c|c|c|c|}
\hline Adipose tissue & $\begin{array}{l}\text { Fat-producing capacity } \\
\qquad \overline{\text { FPC }}=\frac{\frac{F}{\text { FFT }}}{n}\end{array}$ & $\begin{array}{c}\begin{array}{c}\text { Catalase activity } \\
V_{\max }\end{array} \\
\overline{\mathrm{CA}}=\frac{\frac{\bar{t} \cdot \mathrm{FFT}}{n}}{}\end{array}$ & $\overline{C A} \times \overline{F P C}$ \\
\hline $\begin{array}{l}\text { Subcutaneous tail fat } \\
\text { Perinephric fat } \\
\text { Pericardial fat } \\
\text { Intestinal fat }\end{array}$ & $\begin{array}{l}6.67 \pm 7.64 \\
38.39 \pm 13.92 \\
15.68 \pm 6.72 \\
15.07 \pm 5.72\end{array}$ & $\begin{array}{l}2.88 \pm 1.28 \\
8.52 \pm 5.27 \\
3.09 \pm 1.22 \\
3.30 \pm 1.66\end{array}$ & $\begin{array}{r}22.29 \\
380.30 \\
47.71 \\
55.06\end{array}$ \\
\hline
\end{tabular}

$r_{\text {CA, FDC, } 3 \text { steers }(n=12)=+0.750 \pm 0.089 \quad P<0.01}$

${ }^{r} \mathrm{CA}, \mathrm{FPC}, 3$ steers $(n=12)=+0.844 \pm 0.058 \quad P<<0.01$ 
divergencies were found. Sensory testing of boiled and roasted samples also did not reveal any flavour divergencies either in the vapour from the boiling vessel or in cut samples. The colour, odour and taste were typical and specific.

The results of the analysis are summarized in Tables $1-6$ showing mean values $(\bar{x}) \pm$ standard deviations (S. D.) and percentages of variation (V). The significance of the differences between Groups I and II at the $5 \%$ level is designated $\downarrow$ or $\uparrow$ and at $1 \%$ level $\downarrow \downarrow$ or $\uparrow \uparrow$ depending on whether the level of the characteristic in Group II fed swine waste till slaughter was lower or higher than in Group I where swine waste was withdrawn from the diet 25 days before slaughter.

\section{Discussion}

The findings that the experimental steers fed concentrated swine waste as part of the diet were in a very good nutritional condition and had no pathoanatomical changes that could be related to the experimental diet at post-mortem inspection suggested that the general state of the animals was apparently unaffected. This was an encouraging result. Similarly, sheep and cattle fed a diet containing as much as 50 per cent dried swine faeces for 9 days ate and grew well (Hennig et al. 1972, 1973) and their health status was therefore unaffected by the diet. Harmon et al. (1973) in experiments with pigs fed a diet containing aerobically or anaerobically processed swine waste found no changes in the lymphatic system and liver and reported that the carcasses were fit for human consumption.

Dressing percentage was in keeping with the nutritional status grade and its mean value, 58.77 per cent, corresponded to that of young medium-fattened cattle (55 to 60 per cent - Kahoun et al. 1967). The lowest dressing percentage was found in one of the steers fed cattle cake in place of swine waste for the last 25 days before slaughter, whereas the highest dressing percentage (more than 60 per cent) was recorded in one animal fed swine waste till slaughter. There were no significant differences between Groups I and II in either live body mass or dressing percentage. That the nutritional status was very good appears also from the mean total separated adipose tissue mass $(15.80 \mathrm{~kg})$ that exceeded the value $(13.19 \mathrm{~kg})$ reported for the Bohemian Red Spotted breed (Kahoun and Zemánek 1964). It constituted, on average, $3.23 \%$ of live body mass, but significantly $(P<0.01)$ more in Group I $(4.0 \%$ vs. $2.47 \%)$. A significant $(P<0.05)$ difference between Groups I and II was recorded also for perinephric fat. This finding does not reduce the carcass value of steers receiving swine waste till slaughter in any case; indeed, it suggests a higher rate of fat deposition in Group I. The results of basic carcass evaluation are in keeping with the data reported for Bohemian Red Spotted steers (Kahoun et al. 1967), though the experimental animals were, on average, $24 \mathrm{~kg}$ heavier at slaughter, which apparently accounts for their higher fat content values. The proportions of meat, bone, fat and tendon in the individual three main cut parts of the carcasses were almost the same in Groups I and II. No significant differences between the two groups were found in the proportions of bone and tendon. However, the proportions of meat in shoulder and strip loin and the proportion of fat in shoulder were significantly $(P<0.01)$ higher in steers fed swine waste till slaughter.

Another favourable result was the outcome of sensory testing: the heat-treated meat showed no divergencies from the normal in odour and taste in agreement with the observations reported by other writers (Diggs, Baker and James 1965; Orr et al. 1971; Wax, Harmon and Schmidt 1972). 
Evaluation of the physiological condition of the experimental steers on the basis of some biochemical indicators of the blood collected at slaughter revealed a significantly $(P<0.01)$ lower lactic acid level $\left(2.11\right.$ vs. $\left.4.88 \mathrm{mmol}^{-1}\right)$ and a significantly $(P<0.05)$ lower urea level $\left(4.51\right.$ vs. $\left.5.18 \mathrm{mmol}^{-1}\right)$ in steers fed pig waste till slaughter; this can be regarded as a positive phenomenon, since the lactic acid level approached the lower limit of the clinical value for cattle $\left(1.78 \mathrm{mmol}^{1-1}\right.$ Vasiljeva 1974) and the urea level was within the range of variation reported by the aforementioned writer. The two findings suggested a well-balanced preslaughter state of the experimental steers. On the other hand, the value of $16.76 \mathrm{mmol} 1^{-1}$ recorded for inorganic phosphorus is approximately twice the concentration reported for steers (7.24 mmol.1 ${ }^{-1}$ - Vasiljeva 1974), which might be interpreted to indicate a higher rate of nucleotide breakdown. However, the absence of significant differences in inorganic phosphorus level between Groups I and II suggests that the increased values were due to slaughter stress.

The basic meat composition, a deciding factor in the nutritional value of meat, agreed very well with the mean value for beef $(73.3 \%$ water, $21.3 \%$ protein, $1.045 \%$ ash - Souci, Fachmann and Kraut 1962). On the other hand, the 0.79 per cent fat content in $\mathrm{m}$. longissimus dorsi was 1 to 2 per cent lower, which might be accounted for by rigorous separation of external fat. A very similar fat content of the same muscle was reported by Lawrie (1974). In any case, low intramuscular fat content cannot be regarded as a drawback. The diaphragm fat content in Group II was significantly $(P<0.05)$ higher than in Group I, but still rather low $(2.99 \%)$ for red muscle. The mean muscleglycogen content was $8.1 \mathrm{~g} . \mathrm{kg}^{-1}$, thus approaching the upper limit of the range of 1.0 to $11.0 \mathrm{~g} . \mathrm{kg}^{-1}$ as reported by Souci, Fachmann and Kraut (1962). This implies that the muscle energy reserves were not exhausted and that the steers were not excessively stressed. From the viewpoint of meat ageing a sufficiently high meat glycogen level can be regarded as a positive feature. Another merit can be seen in the fact that total meat pigment (myoglobin + hemoglobin) content of the diaphragm and $\mathrm{m}$. longissimus dorsi was significantly $(P<0.05)$ lower in steers fed swine waste till slaughter. Total pigment content of the $\mathrm{m}$. longissimus dorsi was 0.1 per cent lower than the value reported by Lawrie (1974); pigment content of the diaphragm, a dark muscle, was relatively low $\left(8.87 \mathrm{~g} . \mathrm{kg}^{-1}\right)$. Considering that the consumer generally prefers pale beef, the finding of a relatively low content in our experimental steers and particularly in those of Group II is a positive feature. The available published data on collagen content of $\mathrm{m}$. longissimus dorsi vary considerably, comprising such differing values as 1.74 per cent in 22-month old steers (Hill 1966), 4.5 per cent (Herring, Cassens and Briskey 1967) and 0.8 to 1.2 per cent (Baláž and Izák 1972). The 0.78 per cent collagen content of m. longissimus dorsi in our study is at the lower limit of this range. The finding of a low value ( 0.82 per cent) in the diaphragm, too, suggests that an important role should be ascribed to the preparation of the sample before processing. The collagen found can therefore be regarded as purely intramuscular. The calculated percentage contribution of connective tissue to total protein was also relatively low, although it was significantly $(P<0.05)$ higher in the $\mathrm{m}$. longissimus dorsi of steers fed swine waste till slaughter.

The mean $\mathrm{pH}$ value (6.18) for $\mathrm{m}$. longissimus dorsi in our study was in keeping with the $\mathrm{pH}$ of meat one hour post mortem (6.20) as reported by Matyás et al. (1965). In steers fed swine waste till slaughter the $\mathrm{pH}$ was significantly $(P<0.05)$ higher (6.40 vs. 5.95$)$ and the difference between the two groups persisted after 
ageing of the meat in a cold room for 9 days, with the $\mathrm{pH}$ values being 5.61 as against 5.49. Less acidification of the meat from steers fed swine waste is a negative feature. Nevertheless, even the $\mathrm{pH}$ value found in Group II is low enough to protect meat from bacterial decomposition and corresponds essentially to that reported for aged meat (Matyáš et al. 1965). Glucose content of the m. longis-

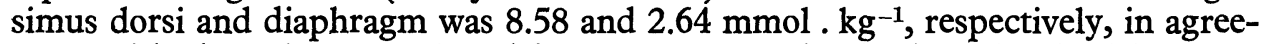
ment with the values mentioned by Krylova and L jaskovska (1961). However, in Group II the glucose content was significantly $(P<0.05)$ lower than in Group I. Lactic acid content of the m. longissimus dorsi in Group II was also significantly $(P<0.05)$ lower than in Group I, similarly to the trend of lactic acid content of the blood. This is in keeping with the finding of a higher $\mathrm{pH}$ in Group II. The mean lactic acid values from all six experimental acid values taken together agreed well with the data on meat ageing (Matyás et al. 1965). The same applied to the content of inorganic phosphorus and indicates a normal rate of breakdown processes.

Nonprotein nitrogen content of the $\mathrm{m}$. longissimus dorsi expressed in terms of percentages of total nitrogen was 11.4 per cent, a value very close to 11.6 per cent reported for $\mathrm{m}$. longissimus dorsi by Lawrie (1974); in the diaphragm the value was even lower, amounting to orly 10.2 per cent. There were no differences in this respect between Groups I and II. Free amino acid (ninhydrin-positive substances) levels in the two muscles were also low; the values for m. longissimus dorsi showed a significant $(P<0.05)$ difference between the two groups, being lower in the group of steers fed swine waste till slaughter. For our mean ammonia values of 7.57 and $3.52 \mathrm{mmol} . \mathrm{kg}^{-1}$ for $\mathrm{m}$. longissimus dorsi and diaphragm, respectively, no published data on fresh beef were available for comparison. Considering that Smorodincev (1952) reported a value of $3.11 \mathrm{mmol} . \mathrm{kg}^{-1}$ for meat on the 1st day of ageing, the present warm-meat-ammonia values were enhanced; however, in steers fed swine waste till slaughter the levels were significantly $(P<0.01)$ lower than in Group I. That this is an argument in favour of swine waste feeding appears also from the fact that the mean ammonia value after 9 days of ageing in a cold room did not exceed $12.91 \mathrm{mmol} . \mathrm{kg}^{-1}$, whereas the critical value for aged meat was reported to range between 14.68 and $17.61 \mathrm{mmol} . \mathrm{kg}^{-1}$ (Smorodincev 1952). In the diaphragm, the content of ammonia after 9 days was below $11.74 \mathrm{mmol} . \mathrm{kg}^{-1}$ and significantiy $(P<0.01)$ lower as against Group I.

Meat quality depends to a considerable degree on fat composition which is affected by feeding (Hartfiel 1967). Therefore it is another argument in favour of swine waste feeding that the fatty acid pattern of all fats under study (Table 5) was in keeping with the published data (Ingr 1970). In the present study the level of palmitic acid was remarkably stable. In depot fats the ratio of saturated to unsaturated fatty acids is given mainly by the ratio of stearic to oleic acid. Although oleic acid content of the intestinal fat was significantly $(P<0.01)$ lower in Group II than in Group I, the difference did not make itself felt in the evaluation of total saturated or unsaturated fatty acids. Difference between Groups I and II were observed in some fats (a significantly $(P<0.05)$ lower palmitooleic acid content and a significantly $(P<0.05)$ higher total saturated fatty acid content in the subcutaneous tail fat; a significantly $(P<0.05)$ higher margaric acid content in the pericardial fat), but no trends could be inferred from these findings. A rather unfavourable finding was a significantly $(P<0.01)$ lower linoleic acid content of the intestinal fat, but since this difference was found only in one of the six adipose tissues under study, in cannot be regarded as a result 
of the diet either. Morever, intestinal adipose tissue is not used for production of cooking fats and the findings is therefore not relevant from the nutritional point of view. On the other hand, intramuscular fat in the diaphragm differed from depot fats by a relatively high (almost double) content of linoleic acid. Fatty acid composition of the $\mathrm{m}$. longissimus dorsi showed a higher content of unsaturated fatty acids as compared with diaphragmatic fat. This was given by a change in the ratio of stearic to oleic acid. Little difference between the two muscles was found in the properties of the other fatty acids. The aforementioned stability of palmitic acid content and a competitive relation between stearic and oleic acid in fats from bovine organs were also reported by Waldmann, Suess and Brungardt (1968). The resuls reported here imply that the ration containing swine waste did not affect fatty acid composition of either intramuscular or depot fats.

When the adipose tissues from steers fed swine waste till slaughter were examined for catalase activity and the results were correlated with their fat-producing capacity, the correlation coefficients were high and in reasonable agreement with the coefficients reported previously (Zatočil, Štíchová and Štícha, 1974). This can be regarded as suggestive evidence that the diet containing swine waste did not affect fat metabolism and that carbohydrates were the source. of the dietary fat.

\section{Conclusion}

The results suggest that feeding swine waste to feedlot steers did not affect the quality of their meat. Further trials are justified.

\section{Vlastnosti jatečného těla a složení masa býků, přikrmovaných dietou se zahuštěnými vepřovými exkrementy}

Byla sledována hodnota jatečného těla a některé vlastnosti masa a tuku pokusných býkủ, přikrmovaných zahuštěnými vepřovými exkrementy $\mathrm{v}$ dietě po několik týdnů. Premortální i postmortální veterinární prohlídkou byl shledán velmi dobrý výživný stav zviŕat a jatečných těl, a žádné zdravotní poruchy související s krmným režimem. Smyslové vlastnosti masa byly typické, specifické. Výtěžnost, podíl dělených částí jatečného těla $i$ jednotlivých tkání dělených částí odpovídaly hodnotám uváděným pro býčky českého strakatého plemene. Složení masa bylo $\mathrm{v}$ přijatelných mezích odpovídajících hovězímu masu. Skladba mastných kyselin tukové tkáně svalů i tukových pletiv a tukotvorné vlastnosti tukových pletiv, hodnocené podle aktivity katalázy, odpovídaly hodnotám udávaným pro skot. Sledované charakteristiky ve tkáních pokusných býků nebyly viditelně ovlivněny použitou biotechnologií.

Свойства бсенского тела и состав мяса быков, псдкармливаемых диетой с загущенными свиными экскрементами

Проводились наблюдения величин боенского тела и некоторых свойств мяса и жиров подопытных быков, подкармливаемых свиными әкскрементами в диете в течение нескольких недель. На основе ветеринарного осмотра до и после убоя было выявлено очень хорошее состояние питания животных и боенских тел и не было установлено никаких нарушений с точки зрения здоровья, связанных с режимом питания. Чувственные свойства мяса были типичными и специфическими. Выход, доля деленных частей боенского тела 
и отдельных тканей деленных частей находились в соответствии с данными, приводимыми для быков чешской пестрой породы. Состав мяса находился в приемлемых пределах, отвечающих мясу крупного рогатого скота. Структура жирных кислот жировой ткани мышцей и жировых тканей и жирообразовательных свойств жировых тканей, оцениваемых по активности каталазы, соответствовали величинам, приводимым для крупного рогатого скота. Наблюдаемые в тканях подопытных быков характеристики не находились под явным влиянием используемой биотехнологии.

\section{References}

ARNETH, W. - HAMM, R.: Untersuchungen zur Metodik der Hydroxyprolinbestimmung in Fleisch und Fleischwaren. Fleischwirtschaft, 51, 1971: 1523-1526.

BALÁZ̆, J. - IZÁK, S.: Ưčinok skrmovania vysokých dávok močoviny na obsah väzivových a plazmatických bielkovin v mäse volov. Folia vet., Košice, 16, 1972: 205-209.

DIGGS, B. G. - BAKER, J. - JAMES, F. G.: Value of pig faeces in swine finishing rations. J. Anim. Sci., 24, 1965: 291.

DVOǨ́K, Z.: Použití mikrodifúzních metod v potravinářském průmyslu. Prům. Potravin, 8, 1958, č. $6: 1-3$.

EL-SABBAN, F. M. F. - BRATZLER, T. A. - LONG, T. A. - FREAR, D. E. H. - GENTRY, R. F.: Value of processed poultry waste as a feed for ruminants. J. Anim. Sci., 31, 1970: $107-111$.

FONTENOT, J. P. - WEBB, K. E. Jr.: Health aspects of recycling animal wastes by feeding. J. Anim. Sci., 40, 1975: 1267-1277.

GRAU, R. - HAMM, R.: Über das Wasserbindungsvermögen des Säugetiermuskels. II. Über die Bestimmung des Wasserbindung des Muskels. Z. Lebensmittelunters. Forsch., 105, 1959: $337-347$.

HARMON, B. G. - DAY, D. L. - BAKER, D. H. - JENSEN, A. H.: Nutritive value of aerobically or anaerobically processed swine waste. J. Anim. Sci., 37, 1973: 510-513.

HARTFIEL, W.: Die Fettsäurenverteilung in Fleisch und Depotfetten von Mastkälbern undbullen im Hinblick auf eine Qualitätsbeurteilung. Fleischwirtschaft, 47, 1967: 487-490.

HENNIG, A. - SCHULER, D. - FREYTAG, H. H. - VOIGT, C. - GRUHN, K. - JEROCH, H.: Erste Untersuchungen über den Einsatz von Schweinekot in der Rindermast. Vorläufige Mitteilung. Jahrbuch für Tierernährung und Fütterung, 8, 1972-1973: 226-234.

HENRY, J.: Clinical chemistry. Harper, Row Publishers, New York 1964. 1128 p.

HERRING, H. K. - CASSENS, R. G. - BRISKEY, E. J.: Factors affecting colagen solubility in bovine muscles. J. Fd. Sci., 32, 1967: 534-538.

HILL, F.: The solubility of intramuscular collagen in meat animals of various ages. J. Fd. Sci., 31, 1966: 161-166.

HOLUB, A. et al.: Fyziologie hospodářských zviŕat. SZN, Praha 1969. 673 p.

HOMOLKA, J.: Klinické biochemické vyšetřovací metody. Avicenum, Praha 1971. 506 p.

HORNSEY, H. C.: The colour of cooked cured meat. I. Estimation of the nitric oxide haem pigments. J. Sci. Fd Agric., 1956: 534-540.

HOŘEJŠÍ, J.: Základy chemického vyšetřování v lékařství. SZdN. Praha 1964. 693 p.

INGR, I.: Změny složení tuků prasat, skotu a drůbeže vyvolané intravitálními vlivy. Thesis, University of Chemistry and Technology, Praha 1970.

INGR, I.: Relation between topography and fatty acid composition of adipose tissues on pigs. Acta vet. Brno, 40, 1971: 163-170.

KAHOUN, J. et al.: Výroba hovězího a telecího masa. Praha 1967. 315 p.

KAHOUN, J. - ZEMÁNEK, P.: Hodnocení intenzity růstu, tělesných rozměrů a jatečné výtěžnosti vykrmovaných býčků plemene červenostrakatého, červeného dánského a jejich kříženců při stejné úrovni výživy. Sb. VŠZ, Brno, 2, 1964: 293.

KEIL, B. - ŠORMOVÁ, Z.: Laboratorní technika biochemie. Nakl. ČSAV, Praha 1959. 872 p.

KRYLOVOVÁ, N. N. - LJASKOVSKÁ, J. B.: Biochémia mäsa. Slov. vyd. techn. lit., Bratislava $1961.380 \mathrm{p}$.

LAWRIE, R. A.: Metabolic stresses which affect muscle. In: The physiology and biochemistry of muscle as food. Univ. of Wisconsin Press, Madison, Milwaukee, London 1966. 436. p

LAWRIE, R. A.: Meat Science. Pergamon Press, Oxford 1974. 419 p.

LEPKOVSKY, S.: Nutritional stress factors and food processing. Adv in Fd Res., 4, 1953: 105 to 128. 
MATYÁŠ, Z. et al.: Hygiena potravin. I. Maso a masné výrobky. SZN, Praha 1965. 630 p.

ORR, D. E. - MILLER, E. R. - KU, P. K. - BERGAN, W. G. - ULLREY, D. E.: Recycling of dried waste in swine. J. Anim. Sci., 33, 1971: 1152.

Prozatímni zkušební metody pro maso, masné poloprodukty, masné výrobky a solící směsi. ZKÚPP Praha a VÚMR, Brno 1958, 171 p.

Sbornik veterinárních předpisů. II. Min. zeměd., les. a vod. hosp., Praha 1962. 670 p.

SÍC, J. - DEDEK, J.: Ověření vlivu zkrmování zakoncentrovaných prasečích exkrementů u býků na výkrm. Project report, Pohořelice Research Institute of Animal Nutrition 1975. 9 p.

SMORODINCEV, I. A.: Biochimija mjasa. Pišč. promyšl., Moskva 1952. 382 p.

SOUCI, S. W. - FACHMANN, W. - KRAUT, H.: Die Zusammensetzung der Lebensmittel. Nährwert Tabellen. Wissenschaftliche Verlagsgesellschaft H. B. H., Stuttgart 1962.

ŠVANDA, J. - KOŠKA, V. - NĚMEČEK, B.: Výzkum strojních zařizení na přípravu bílkovinného extraktu $\mathrm{z}$ výkalů prasat a jeho hodnocení. Project report. Research Institute of Chemical Equipment, Brno 1976. 145 p.

VASILJEVA, E. A.: Kliničeskaja biochimija selskochozjajstvennych životnych. Rosselchozizdat, Moskva 1974. $192 \mathrm{p}$.

WADLEIGH, C. H.: Wastes in relation to agriculture and forestry. U. S. D. A. Misg. Publ., 1965, 1968. Cit.: FONTENOT, WEBB.

WALDMAN, R. C. - SUES, G. G. - BRUNGARDT, V. H.: Fatty acid of certain bovine tissues and their association with growth, carcass and palatability traits. J. Anim. Sci., 27, 1968: 632 to 635.

WAX, J. E. - HARMON, B. G. - SCHMIDT, G. R.: Effect of liquid feeding oxidation ditch mixed liquor on the palatability of pork. J. Anim. Sci., 35, 1972: 1100 .

ZATOČIL, O. - ŠTÍ́CHOVÁ, O. - ŠTÍCHA, F.: Katalázová aktivita v různých druzích tukové tkáně skotu a prasat. Vet. Med., Praha, 19, 1974: 397-406.

\section{ACTA VETERINARIA BRNO}

Čís. $1-2,1978$

Vydala Vysoká škola veterinární v Brně

ve Státním pedagogickém nakladatelství, n. p., Praha

Publikace č. $79-49$

Odpovědný (vědecký) redaktor: prof. MVDr. Antonín Holub, DrSc.

Technický redaktor Antonín Hrachovina

Vytisklo Rudé právo, tiskařské závody Brno

Formát papíru $70 \times 100 \mathrm{~cm}$ - AA 10,90 - VA 11,57

Tematická skupina a podskupina $02 / 58$

Náklad 700 výtisků

Vydání 1.

Cena brožovaného výtisku Kčs 21,00

$509 / 21,827$

14-765-79 Kčs 21,00 

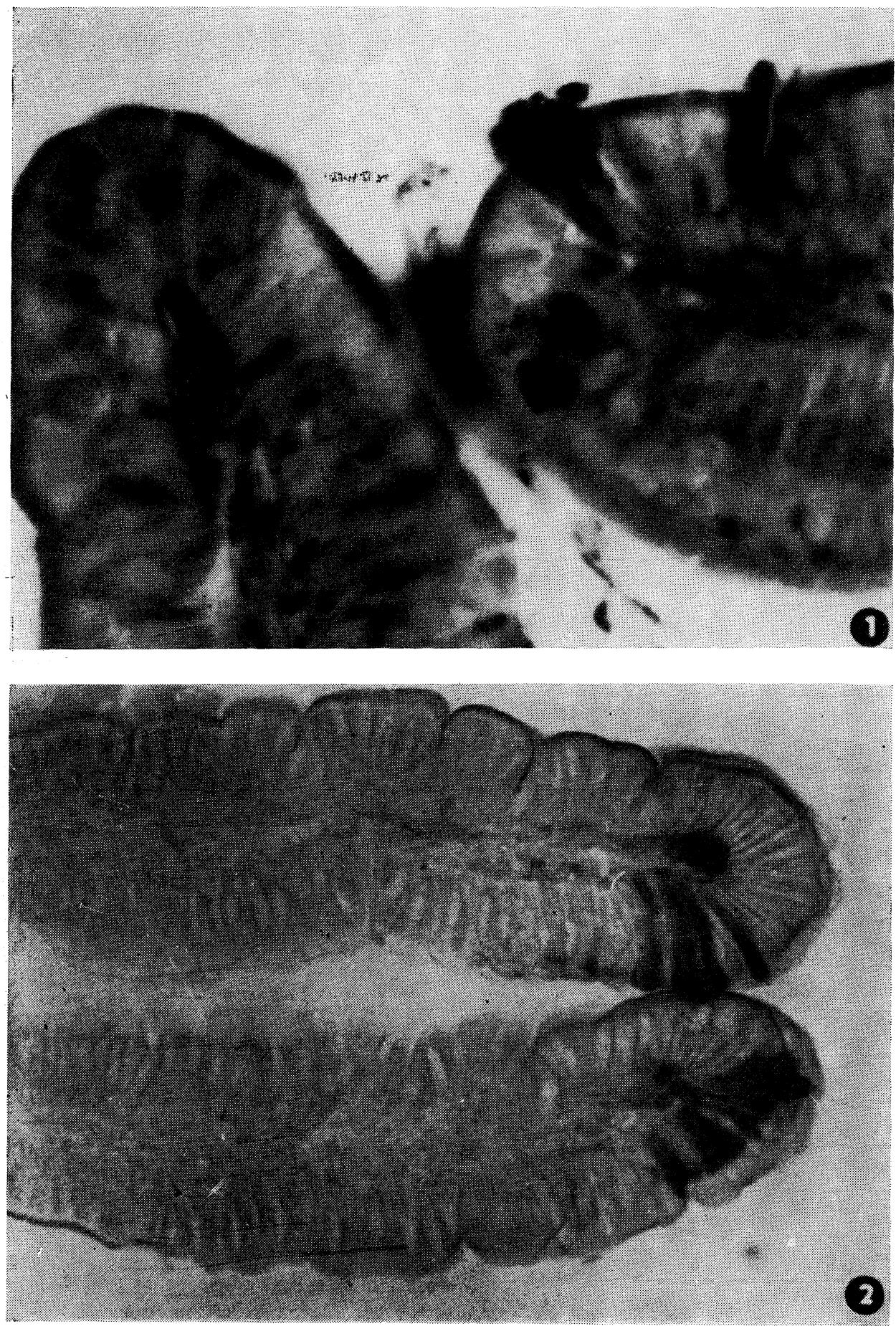

Plate I.

Fig. 1.

Transversal section of a jejunal villus after the 5-minute exposure. Exogenous peroxidase present in the terminal web and senescent enterocytes. Counterstained with hematoxylin. $\times 350$.

Fig. 2.

Longitudinal section of jejunal villi after the 10-minute exposure. Exogenous peroxidase present in the terminal web, in the group of senescent enterocytes and in the vicinity of blood capillaries of the villous stroma. $\times 260$. 

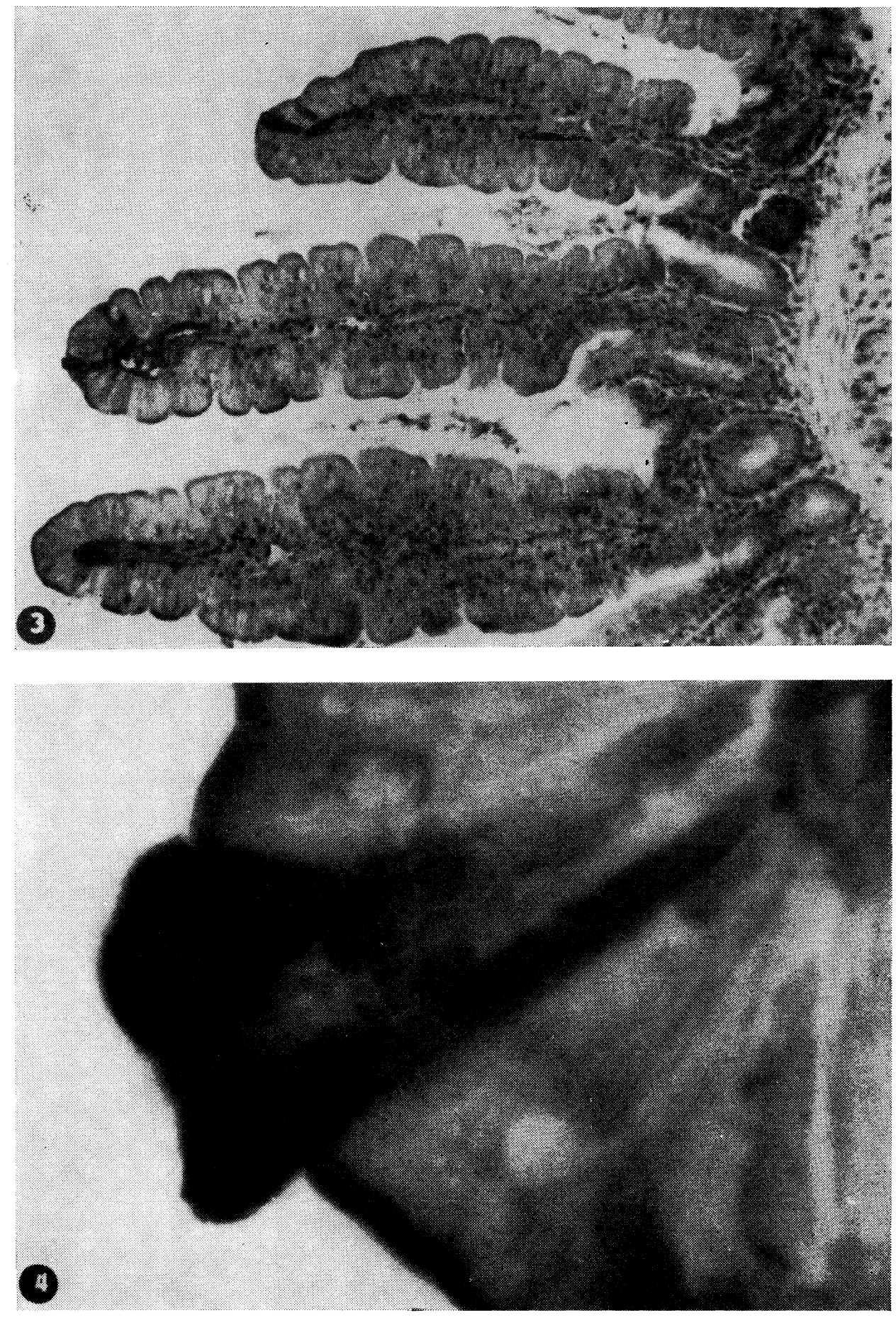

Plate II.

Fig. 3.

Longitudinal section of jejunal villi after the 20 -minute exposure. Exogenous peroxidase present in the vicinity of and in the wall of blood capillaries of the villous stroma. Counterstained with hematoxylin. $\times 230$.

Fig. 4.

Section of the villous epithelium after the 30-minute exposure. Exogenous peroxidase diffusely stained the prominating senescent enterocytes. $\times 3600$. 

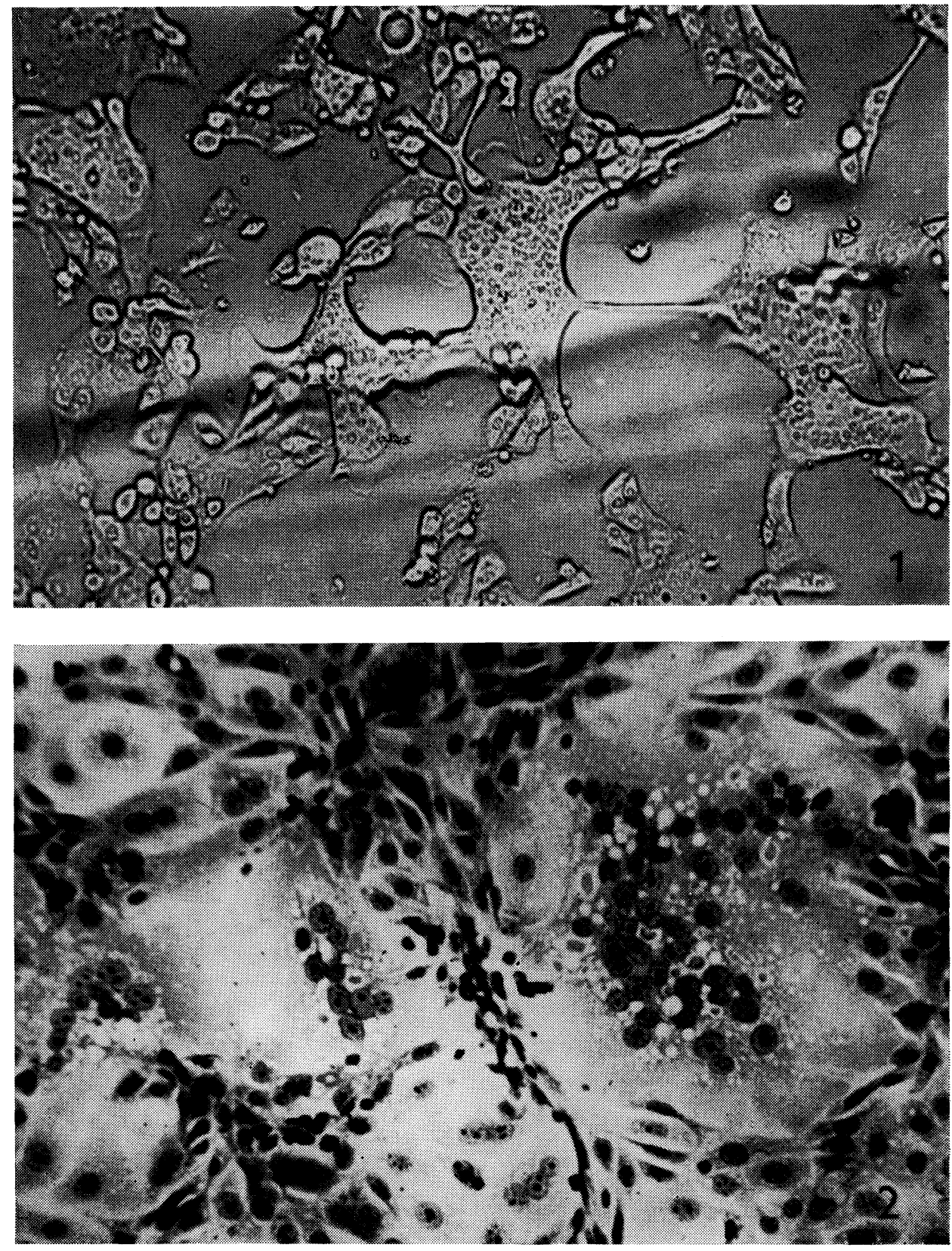

\section{Plate III.}

Fig. 1.

Syncytia in a FBK cell culture 6 days after infection with the bovine RSV isolate in the 8th passage. Unstained. $\times 120$.

Fig. 2.

Multinucleated syncytia in a FBK cell culture 6 days after infection with the bovine RSV isolate in the 9th passage. Haematoxylin and eosin. $\times 320$. 

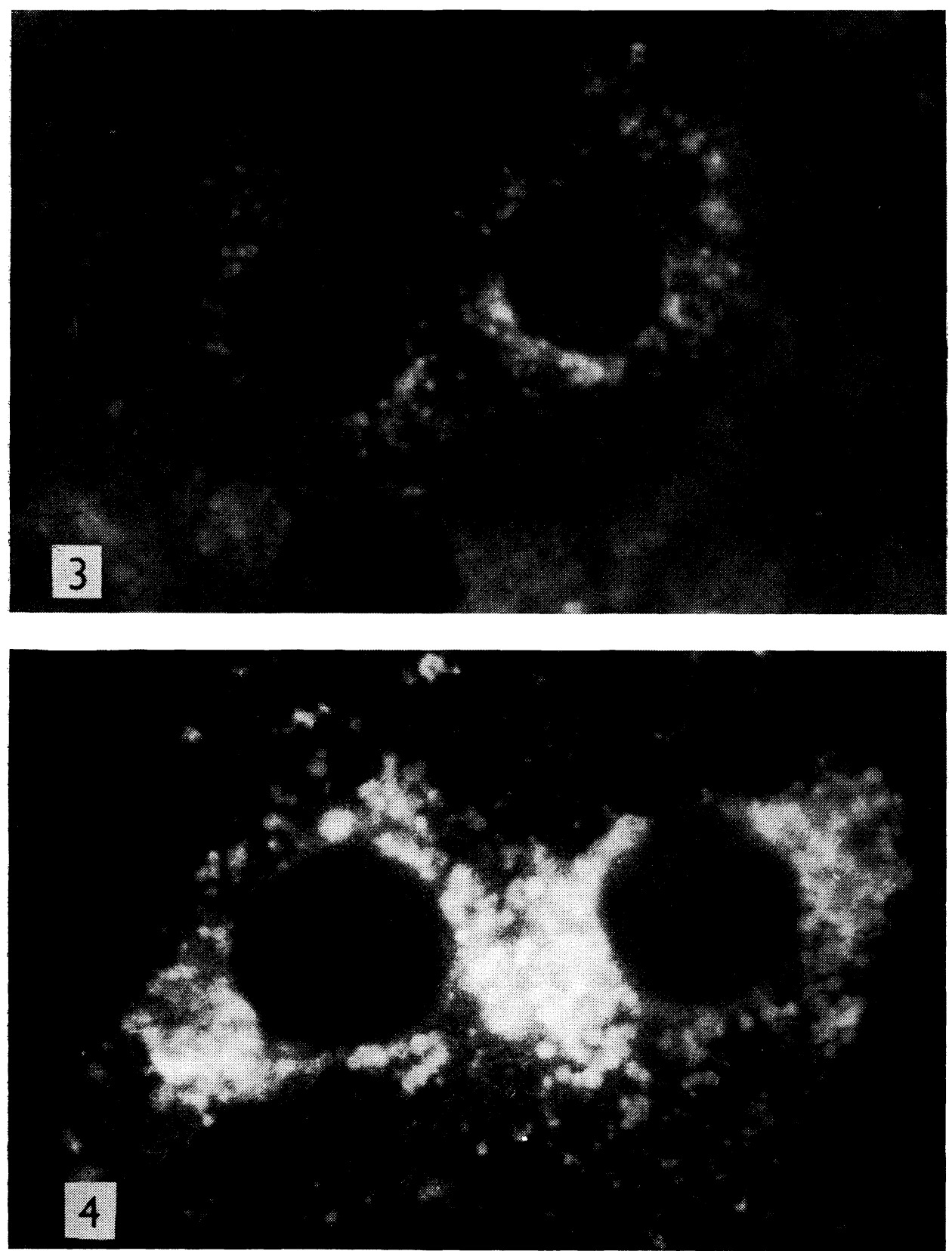

Plate IV.

Fig. 3.

Initial specific perinuclear fluorescence in a FBK cell culture 40 hours after infection with the bovine RSV isolate in the 8th passage. $\times 620$.

Fig. 4.

Specific fluorescence in a FBK cell culture 72 hours after infection with the bovine RSV isolate in the 8th passage. $\times 620$. 

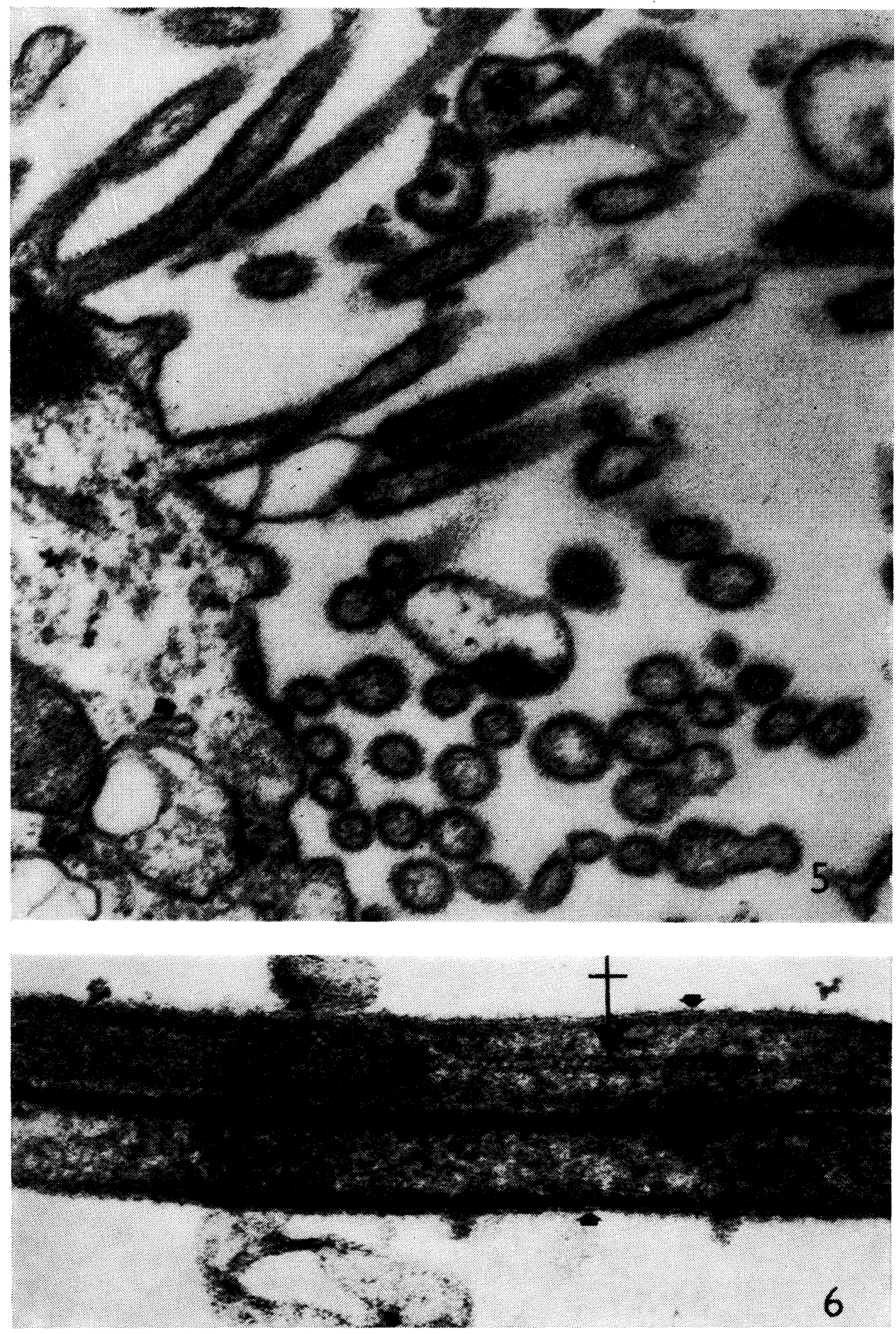

\section{Plate V.}

Fig. 5.

Filamentous viral particles budding from the plasma membrane and extracellular spherical particles. $\times 48000$.

Fig. 6.

Parts of two filamentous viral particles showing a distinct unit membrane structure of the envelope (arrows). Note the distinct filamentous structure within one particle (crossed arrow). 